\title{
ヒト唾液腺初代培養細胞の増殖性に及ぼすイソプロテレノールの影響
}

\author{
宮田和幸・岩上好伸・和田健・原田昌和
} 高木健次・森田展雄・坂本忠幸

\section{The effects of isoproterenol on the growth of human salivary gland cells in primary culture}

\author{
Kazuyuki Mryata $\cdot$ Koshin Iwagami = Takeshi Wada \\ Masakazu Harada - Kenji TAKagi • Nobuo Morita \\ Tadayuki SAKamoto
}

\begin{abstract}
The effects of isoproterenol on the outgrowth from human salivary gland explants were studied in primary culture.

Isoproterenol was added to the growth medium to produce a graded series of concentrations of $10^{-4}, 10^{-5}, 10^{-6}$ and $10^{-7} \mathrm{~g} / \mathrm{ml}$.

In the absence of isoproterenol, the cellular outgrowths from salivary gland were easily degenerated after 4-6 weeks of culture, and in most cases fibroblastic growth exceeded epithelial outgrowth.

Isoproterenol did not increase the growth of salivary gland cells when used at doses of $10^{-4}, 10^{-5}$ and $10^{-6} \mathrm{~g} / \mathrm{ml}$.

At $10^{-5} \mathrm{~g} / \mathrm{ml}$, isoproterenol appeared to have the property of maintaining the sheet-like structure of cellular outgrowth.

The inhibitory effect on fibroblastic growth was observed in doses of $10^{-4}, 10^{-5}$ and $10^{-6}$ $\mathrm{g} / \mathrm{ml}$.

These results show that isoproterenol may act as a regulatory factor in the control of the proliferation and differentiation of human salivary gland cells.
\end{abstract}

Key words: salivary gland, culture, human, isoproterenol

\section{緒言}

アドレナリン作動性薬物の 1 つであるイソプロテレノ 一ルは, マウス・ラットに大量投与するとその唾液腺に 肥大をきたすことが，従来より注目されている1,2). in vitro に拈いては，イソプロテレノールがマウス，ラッ トの唾液腺由来細胞に対して，その增殖を促進するとい

和歌山県立医科大学㐘科口腔外科学教室

（主任：坂本忠幸教授）

Department of Dentistry and Oral Surgery, Wakayama Medical College (Chief: Prof. Tadayuki Sakamoto)

受付日：昭和 62 年 7 月 25 日
う報告が多いものの ${ }^{3,4)}$, 逆に抑制的に働くとする報告 もなされている5)

一方，マウス・ラットを用いた唾夜腺発癌実験におい ても，イソプロテレノールがこれを促進する ${ }^{6)}$, および, 抑制する7)，といら報告がなされており，結論は出てい ない。また, 臨床的にも，イソプロテレノールの長期投 与をらけている喘息患者において唾液腺の腫脹をきたし た症例が報告されているが，因果関係は必ずしも明らか ではない8)

しかしながら, 以上の実験結果や症例報告から、ヒト 量液腺細胞の增殖過程に対しても, イソプロテレノール が何らかの影響を及ぼしている可能性は大きいものと考 えられる.

そこで，われわれは，ヒト唾液腺由来細胞を用いて， 培養液中に種々の濃度のイソプロテレノールを添加し, 
上皮様細胞および線維芽細胞様細胞の増殖・形態に及ぼ す影響について検討を加えた。

\section{実 験 方 法}

\section{(1) 採取林料}

培養材料としては，手術時に得られたヒト㴿下腺，口 唇腺を用いた。採取症例は, 顎下腺の場合は, 口腔癌の 頸部郭清に伴うもの，腺体内唾石で摘出されたものなど であり，口唇腺の場合は，大部分が下唇部粘液襄胞の摘 出に伴らものである．材料採取に際しては特に無菌操作 に留意し，また，採取材料の中でも，できるだけ，変 性・萎縮をきたしていない部分を選択した。

\section{（2）培養方法}

無菌的に得られた買下腺・ロ唇腺をメスで $1 \mathrm{~mm}^{3}$ 以 下に細切し，カバーグラス（マッナミ，22 mm）上に直 接貼りつけて，それを $35 \mathrm{~mm}$ 径プラスチックシャーレ (Falcon) 内に静置して, BME 培地 (GIBCO) を加光 た。なお， $\mathrm{BME}$ 培地には新生仔牛血清（中標律血清， 三菱化成）を最終濃度 $20 \%$ となるように加え，さらに抗 生物質として, ペニシリン $100 \mathrm{U} / \mathrm{ml}$, ストレプトマイ シン $100 \mu \mathrm{g} / \mathrm{m} l$, ファンギゾン $0.25 \mu \mathrm{g} / \mathrm{ml}$ (いずれも GIBCO 製, 最終濃度) を添加し， $\mathrm{pH}$ を7.2〜7.4 と なるよう調整した。これらのシャーレを $5 \% \mathrm{CO}_{2}$ ，飽和 湿度と $37^{\circ} \mathrm{C}$ に調節された炭酸ガスインキュベータ（ヤ マト, IP-31）内で培養した。培地の交換は週 2 回行っ た.

イソプロテレノールは，DL-イソプロテレノール塩酸 塩（Sigma）を, 最終濃度 $10^{-4}, 10^{-5}, 10^{-6}, 10^{-7} \mathrm{~g} / \mathrm{ml}$ となるように培地中に添加した。

\section{（3）增殖の測定}

組織片からの細胞遊走は培養 $3 \sim 12$ 日後頃より始ま り，しだいに充実性の細胞性シートを形成したため，そ の輪廓を，実体影微鏡（ニコン，SMZ-10）に装着した 描画装置でスケッチし，プラニメータ（牛方商会）を用 いて面積を測定した（図１）.

\section{（4）DNA 合成能の測定}

継代中のヒト顎下腺由来線維芽細胞様細胞を 1 well あ たり $10^{4}$ 個ずつ microtestplate (Falcon, 3042) に播種 し，48時間インキュベートした。ささらに各濃度のイソプ ロテレノールを添加して48時間インキュベートした後， ${ }^{3} \mathrm{H}$-チミジン $(0.8 \mu \mathrm{Ci} / \mathrm{ml})$ を添加し, さらに18時間イ ンキュベートした. Multiple cell harvester (WAKEN, Mark II) で cell harvest した後，5\%トリクロール酰 酸, 95\%エタノールで洗浄し, 液体シンチレーションカ ウンター (Packard, 3310) にて，とりこまれた ${ }^{3} \mathrm{H}-$ チミ ジンをカウントした（図 2 ).

(5) 形態の観察

増殖細胞の形態観察には, 倒立位相差顕微鏡の他, カ

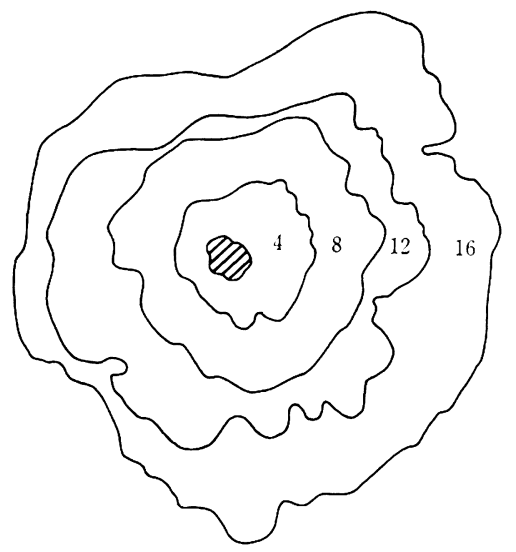

図 1 細胞性シートの輪廓の経日的変化

細胞播種 (104 個/well)

(Falcon microtestplate 3042)

48 時間インキュベーション

isoproterenol 添加

$\downarrow 48$ 時間インキュペーション

${ }^{3} \mathrm{H}-チ$ ミシンの添加

$\downarrow 18$ 時間インキュペーション

multiple cell harvester $て ゙$ cell harvest

$5 \%$ TCA, 95\% ェ タール洗浄

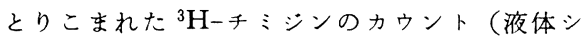

ンチレーションカウンター)

図 2 線維芽細胞様細胞の DNA 合成能の測定

バーグラスをとり出してメタノールまたは中性ホルマリ ン固定の後, ヘマトキシリン・エオジンまたはギムザ染 色を施して検鏡した。

結

果

（1）イソプロテレノール非添加の場合の増殖の経過 組織片からの細胞の遊出は, 培養開始 $3 \sim 12$ 日後頃か らみられ，したいに類円形の上皮細胞性シートを形成し た（写真1）。このシートの面積を実体顕微鏡に装着し た描画装置でスケッチして計測した結果, 培亘開始後約 20 日で最大となる例が多かった。この段階でシート内細 胞を観察すると，多角形ないし不定形の上皮様細胞が単 層状に增殖し，これらの細胞は，“pave”“jigsaw”また は “wheel or cord” 状の配列状態を呈していた（写真 2,3 ).

培盖開始 $3 \sim 4$ 週以後は, かえってシート内の細胞の 欠損が目立ち始め, シートの輪廓も凹凸不整となってい 


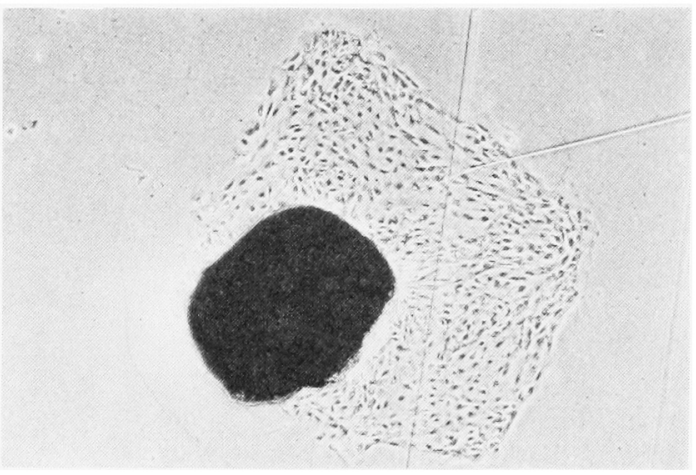

写真 1 培峑 5 日後の胞性シート

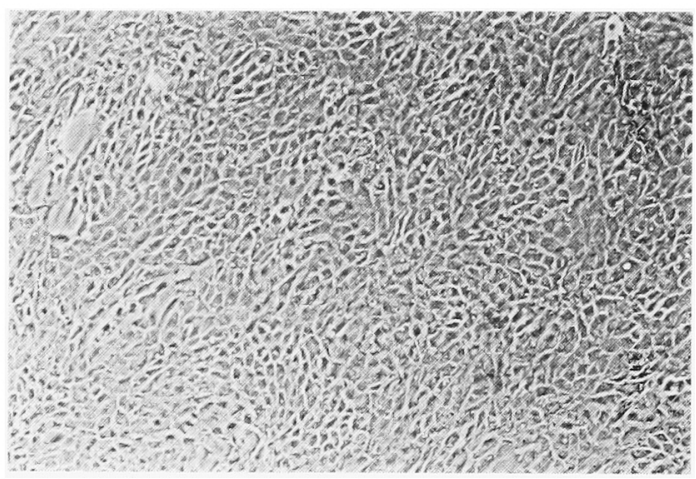

写直 2 “pave” 状に配列した上皮様細胞

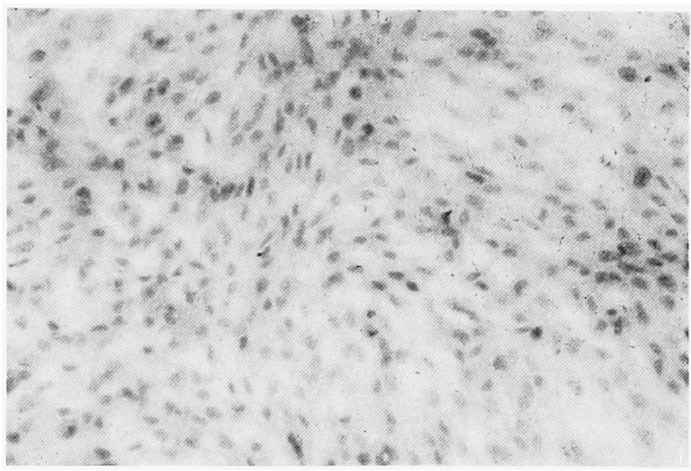

写真 3 “jigsaw”状に配列した上皮様細胞

った。また，その頃より，周辺より線維芽細胞様細胞の 増殖がさかんになり，しだいに，シート内の上皮様細胞 に駆逐されていった（写真 4 ).

（2）細胞性シートの面積の比較

培荃開始約 30 日後に，イソプロテレノール添加群 $\left(10^{-4}, 10^{-5}, 10^{-6}, 10^{-7} \mathrm{~g} / \mathrm{m} l\right)$ および非添加群の細胞 性シートの面積を比较した. $10^{-5} \mathrm{~g} / \mathrm{m} l$ 添加群では, 非

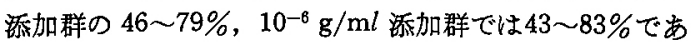

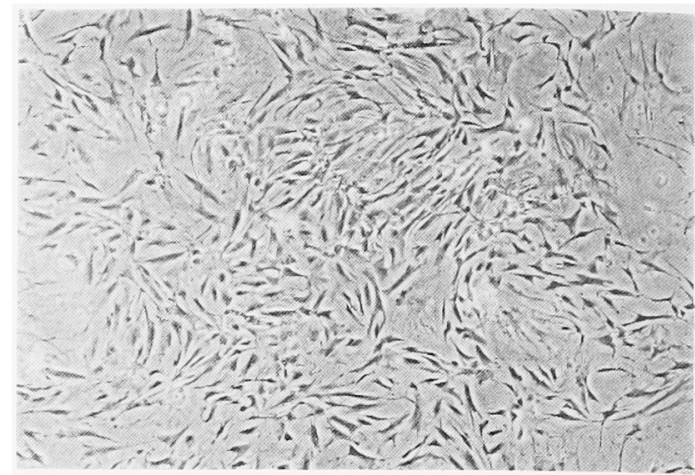

写真 4 線維芽細胞様細胞の增殖（継代 2 代目）

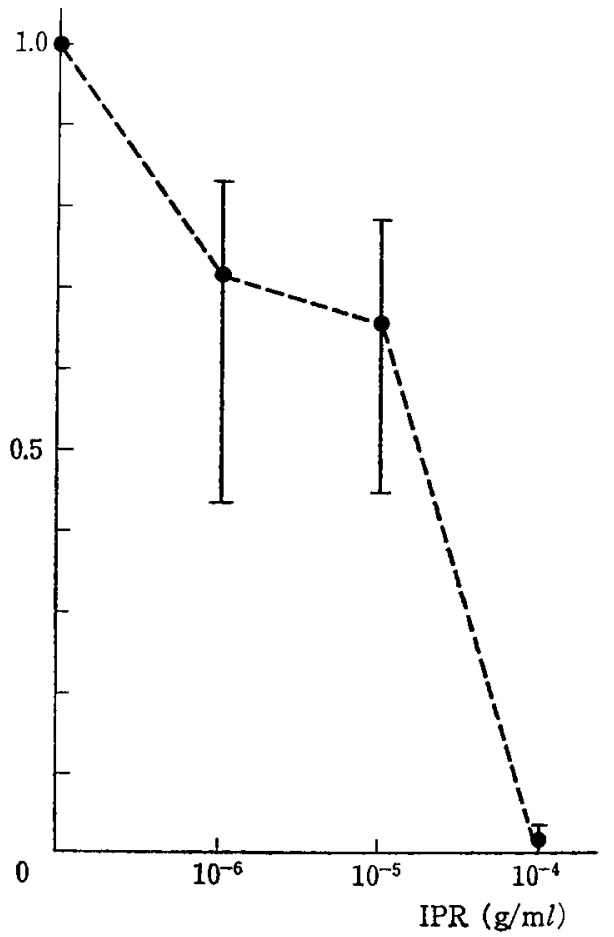

図 3 細胞性シートの面積の比較

った. $10^{-7} \mathrm{~g} / \mathrm{m} l$ では非添加群との間に有意差は認めら

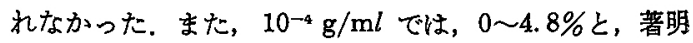
な抑制が認められた（図了）.

（3）細胞性シートの形態の比較

培荃開始約30日後に，細胞性シートの輪廓およびシー ト内部の細胞の配列状態を比較した。その結果，イソプ ロテレノール添加群では，上皮性細胞が充実性火增殖し て類円形の輪廓を呈していたのに対し，同非添加群で は、シートの輪廓が凹凸不整となり, 内部での細胞欠唄 を認めることが多かった。 


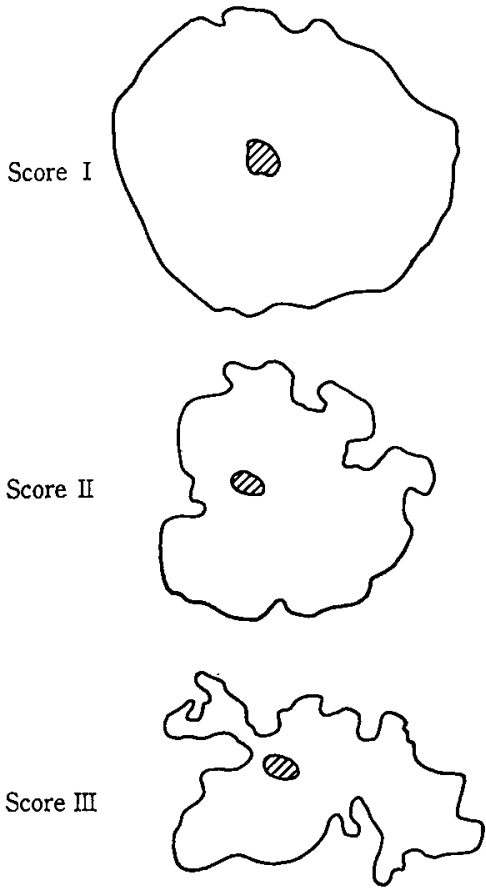

図 4 シートのスコア(シxーマ)

これらの細胞性シートの輪碍 と充実性を比較するた め, 次のごとく score を与えた（図 4).

score I: シート内の細胞が充実性に增殖し，シートの 输廕明膫なるもの (写真 5 ).

score II：ところどころに紐胞の消失を認めるも，概 してシートの輪廓をとどめるすの（写直 6 ).

score III: 紐胞の消失が多く, シートとしての輪廓を とどめない歹の（写真 7).

すなるち， score の低いるのほど，本来の細胞性シー トとしての性格がよく保たれていると考えられる。

この score の平均値を培養開始約 30 日後に各シャ一 レごとに計算して比較した結果, イソプロテレノール添 加群では，大部分が score II 以下であり，シート内で 細胞消失を認めたり，輪敫が凹凸不整となるものはほと んど認められなかった（図 5).

（4）線維芽細胞样細胞が優位を占める頻度

培養30日後, シャーレ中の各組織片ごとに細胞性シー トを観察して，細胞遊走のパターンを“上皮型”“線維 芽細胞型” “未分化型”に三分類した． 各シート内で優 位を占める細胞を観察して，そのシートの遊走パターン を决定し，症例ごと比度を計算した，

その結果, 線維芽細胞様細胞が優位を占めたものは, イソプロテレノール非添加群では 2.2〜37\% であった. ところが, イソプロテレノール添加群では，0５.8\%で あり，著明な線維芽細胞抑制効果を示した（図6）。

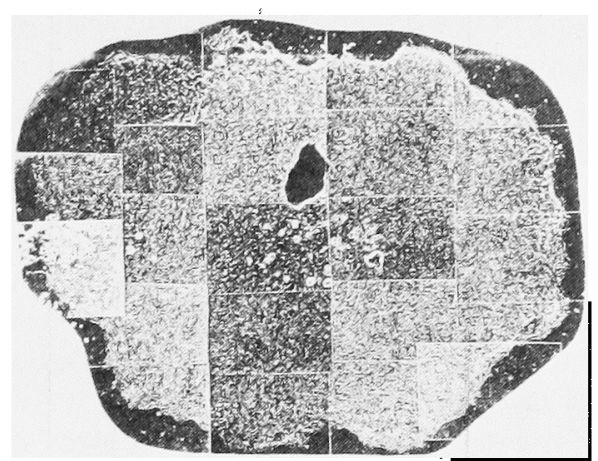

写真 5 score I のシート

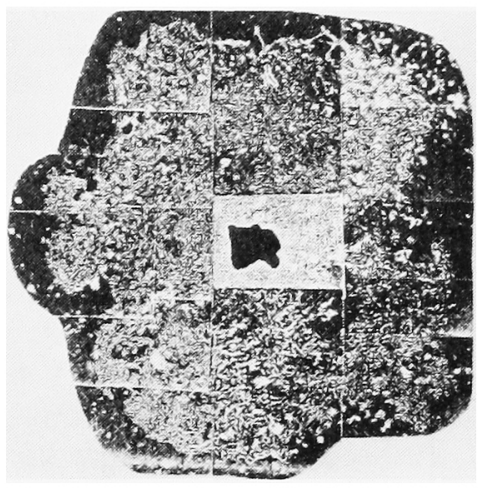

写真 6 score II のシート

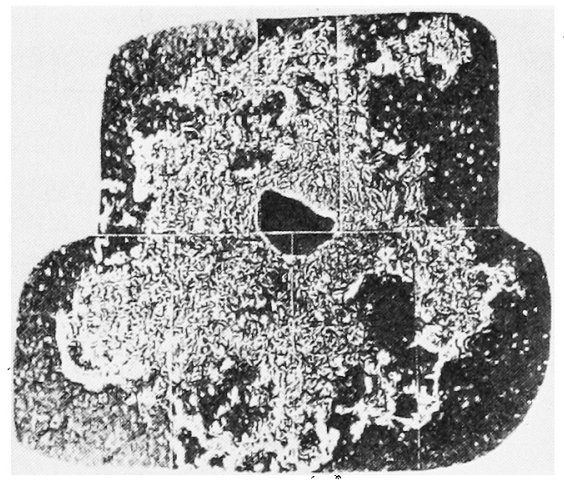

写真 7 score III のシート

この作用は $10^{->} \mathrm{g} / \mathrm{m} l$ の濃度において最も䫒著であ り, $10^{-7} \mathrm{~g} / \mathrm{m} l$ では， 非添加群との差を認めなかった。 一方, $10^{-4} \mathrm{~g} / \mathrm{ml}$ の場合は, 上皮様細胞, 線維芽細胞様 細胞がともに障害されていた。

（5）線維芽細胞様細胞の DNA 合成能

継代 5 代目の䫇下腺由来の線維芽細胞様細胞をマイク ロテストプレートに播種し、 ${ }^{3} \mathrm{H}-$ チミジンのとりこみを 


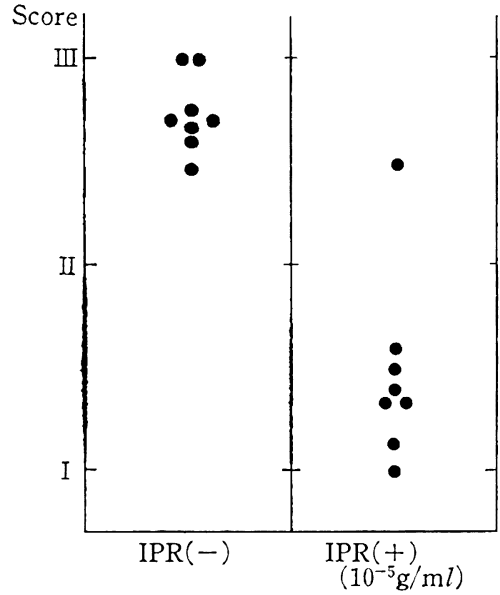

図 5 シートのスコアの比較

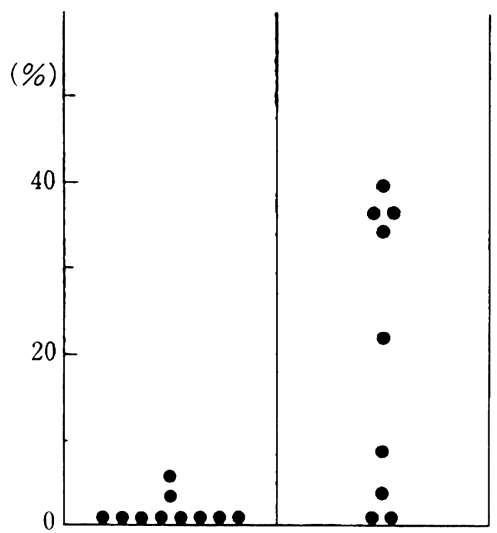

$\operatorname{IPR}(+)$

$\left(10^{-5} \mathrm{~g} / \mathrm{m} l\right)$

図 6 線䊒芽細胞様細胞が優位を占め 万頻度

測定した。 各 well あたりの cpm を比較した結果、イ ソプロテレノール $10^{-0} \mathrm{~g} / \mathrm{m} l$ 涯加群では, 非添加群の59 $\%$, 同 $10^{-6} \mathrm{~g} / \mathrm{ml}$ 添加群では $74 \%$ であり, 著明な DNA 合成能の抑制が認められた（図 7 ).

考察

イソプロテレノール投与により䎑雨類の唾液腺に著明 な肥大および細胞增殖が起こる事実は, 1961年, BrownGrant がマウスに打いで， Selye らがラットにおい で，初めて報告を行った。本来細胞分裂增殖能がきわ めて低いとされる成熟動物の唾夜腺において，このよう な活発な增殖が起こるといら事実は，広く注目され， 以後, マウス・ラットの唾夜腺に対するイソプロテレ
Incorporated radioactivity (count $/ \mathrm{min}$ )

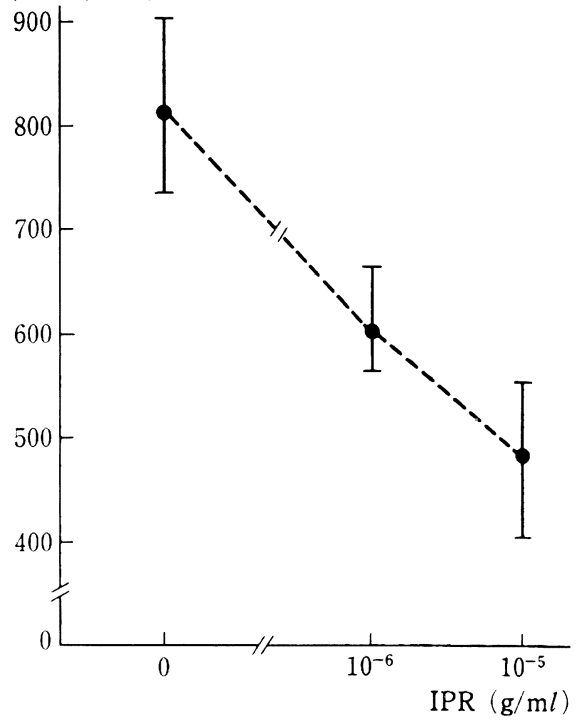

図 7 線維芽細胞様細胞の DNA 合成能

ノールの作用について，多くの動物実験がなされてい $ろ^{3 \sim 5,9 \sim 11)}$

これまでの動物実験により, 唾液腺の細胞增殖は、1 ソプロテレノールの $\beta$ 効果によるものであり，その刺激 がアデニルンクラーゼを活性化し, それによって, cyclic AMP (adenosine $3^{\prime}, 5^{\prime}$-cyclic monophosphate) の細胞 内濃度上昇の起こることが知られている ${ }^{11}$. cyclic AMP はアデニルシクラーゼによって ATPより生成され, cyclic AMP-phosphodiesterase (PDE)によって 5'AMP に分解される。 PDE の阻害剤であるテオフィリンの前 処置により，イソプロテレノールによる唾夜腺 DNA 合 成は增強することが認められている ${ }^{12)}$.

cyclic AMP と細胞增殖との関係については, Southerland によって cyclic AMP が分離されて以来, 多 くの報告があるが, その効果は, 種により, また, 器 官により異なっているようである ${ }^{10)}$ 。 しかし，一般的 に, 線維芽細胞の增殖に対して, cyclic AMP は阻害的 にはたらき，上皮細胞に対しては促進的に作用する傾向 が認められている.イソプロテレノールのほか, コレラ 毒素, プロスタグランディン $\mathrm{E}_{1}$, グルカゴンなどのアデ ニールシクラーゼ活性剤, cyclic AMP 類似物質のジブ チリル cyclic AMP，あるいは 8-bromo cyclic AMP なども細胞内 cyclic AMP 濃度を上昇させて, 上皮細胞 の增殖を促進することが知られている ${ }^{13)}$.

一方，ヒト唾液腺に対するイソプロテレノールの作用 は，ほとんど明らかにされていない，Borsanyi はイソ プロテレノール長期投与患者に㧊ける耳下腺の腫大を報 
告しているが，因果関係は明らかでない'8) イソプロテ レノールを始めとする細胞成長因子の作用は，細胞種に よって大きく異なるものであり，ヒト唾夜腺に対する効 果は，ヒト唾液腺細胞を用いた実験系が必要である。と ころが，唾液腺に限らず，ヒト正常実質細胞（特に上皮 性組織）の培養は困難であり，とりわけ，遊離細胞を得 て増殖させることは，難しい。そこで，本研究では，宮 田の報告した培養条件に従い14)，七ト㴿下腺・口唇腺の 組織片培養を行って, シート状に增殖した初代培羕細胞 について、イソプロテレノールの作用を検討した。組織 片培養の採用は，遊離細胞を得るのが困難であるという たけげなく，この培養法が，細胞培着と器官培養の 2 面 を合わせ持っている，といら積極的な意味をも考虑して いるわけである。

唾液腺培養細胞の増殖性に対するイソプロテレノール の作用については，実験動物（マウス，ラット）細胞を 用いたいくつかの報告がある，Kreider はラット頡下腺 培養細胞で ${ }^{3} \mathrm{H}-$ チミジンのとりこみを観察し， DNA 合 成の促進がみられたとしている゙） また，本間は，ラッ トの耳下腺・顎下腺細胞を用いて，イソプロテレノー ルによる增殖を，細胞数のカウントにより確認してい る4).これに対し， Lamey らは，マウス顎下腺を組織 片培養に供し，イソプロテレノール投与によって增殖抑 制効果が出現し，それは dose-dependent であった，と 報告している5).

本実験においては，ヒト唾液腺の組織片培羑の結果， 形成された細胞性シートの面積は，一般に，イソプロテ レノール添加群 $\left(10^{-5}, 10^{-6} \mathrm{~g} / \mathrm{ml}\right)$ のものが, 非添加 群にくらべて抑制される傾向を認めた。明確に dosedependent であることは示されていないが, $10^{-7} \mathrm{~g} / \mathrm{ml}$ ではその効果は現われず， $10^{-4} \mathrm{~g} / \mathrm{m} l$ では，細胞の遊出 そのものが強く抑制された。 また，細胞性シートを用い てオートラジオグラフを作成し，イソプロテレノールの 添加, 非添加による ${ }^{3} \mathrm{H}$-チミジンのシート内へのとりこ みの差を検討したが，シートを形成する上皮様細胞にお ける labelling index 自体がきわめて低く，(L.I. =0 10.9), 有意差を認めることができなかった。これらの 結果より，組織片培養の細胞性シートで検討した限りで は, ヒト唾液腺細胞に対するイソプロテレノールの増殖 促進作用は認められなかった。

従来の動物実験の報告と異なるこの結果の原因として は、ヒトとマウス，ラットという種の違いの他に，腺房 細胞の含有率の差をも考虑しなければならない. Mangos らは, ラット耳下腺組織をコラゲナーゼ, ヒアルロニダ 一ゼ, トリプシンで酵素処理して得られた細胞には, 95 \%もの腺房細胞が含まれていた，と報告している15) こ れに対して，ヒト唾液腺を組織片培養した場合，シート を形成した細胞の大半は導管由来と考えられ ${ }^{14)}$, 自ずか ら，イソプロテレノールの反応性に差のある可能性もあ
る.

一方，線維芽細胞に対するイソプロテレノールの作用 としては, 初代培盖細胞の線維芽細胞様細胞の遊出頻 度，継代細胞の DNA 合成能について，検討を加えた。 培盖30日後の各細胞性シートを観察して, 線維芽細胞様 細胞が優位を占める頻度を計算した結果，イソプロテレ ノ一ル添加群では，著明な線維芽細胞抑制効果を認めて いる.さらに, 継代 5 代目の線維芽細胞様細胞（顎下腺 由来）の DNA 合成能についても，強い抑制が認められ た。これらの結果より, ヒト唾液腺由来細胞において も, イソプロテレノールは, 細胞内 cyclic AMP の上昇 の結果, 線維芽細胞には抑制的に働いていることが考え られる。

なお, 培着開始 $3 \sim 4$ 週後の時点で, 一定の細胞性シ 一トの周囲から線維芽細胞様細胞が増殖を始めたとき, $10^{-4}$ ないし $10^{-5} \mathrm{~g} / \mathrm{ml}$ のソプロテレノールを数日間な いし数週間（濃度および期間は, シートの状態および線 維芽細胞様細胞の增殖状態により，適宜増減する。ただ し，必ず毎日位相差顕徽鏡で観察を行う）作用させるこ とにより，線維芽細胞様細胞のみを選択的に除去するこ とも可能であった，唾液腺に限らず，上皮性細胞を選択 的に培善しようとする場合, 線維芽細胞様細胞の過剩増 殖が大きな障害となることが少なくない，培地中に一定 濃度のイソプロテレノールを最初から添加することによ って線維芽細胞様細胞の遊出, 增殖を抑制し, また，通 常培地で線維芽細胞様細胞が增殖を始めても, イソプロ テレノールを添加することにより，これを抑制，除去す る効果を期待できるのである.

イソプロテレノールのこのよらな効果は, マウス, ラ ソトの唾液腺培養細胞においては報告されていない。し かし， Lamey らは，マウス顎下腺の組織片培着におい て, 上皮様細胞（E）之線維芽細胞様細胞（F）の此率 (E/F ratio) を計算し，イソプロテレノール $\left(10^{-4} \sim 10^{-6}\right.$ M) 添加によって, E/F ratio は変化しなかった, と述 ベている5) しかし，10-3 M のイソプロテレノール添 加により，移植片が organotypic structure に維持され た，と報告し，イソプロテレノールの特異な性質を強調 している.

本夷験においても，細胞性シートの状態を score をつ けて検討した結果, $10^{-5} \mathrm{~g} / \mathrm{m} l$ のイソプロテレノール涯 加により，ヒト唾液腺由来細胞シートが長期間にわたっ て良好に維持されたことは，正常細胞の維持といら観点 から，興味深いものがある。培差甲状腺で正常な滤胞棈 造を持続するには，TSH，プロスタグランディン $\mathrm{E}_{2}$, ジ ブチリル cyclic AMP など滤胞上皮細胞の働きを刺激 する物質を培地中に加えることが大切であるとされてい る ${ }^{16,17)}$ 。また，唾液腺においても，Oliver は，ラット 耳下腺細胞を培養し，培地中につねに $10^{-6} \mathrm{M}$ のイソプ ロテレノールを添加しておくことによって，腺房細胞の 
分泌能が長期間維持された，と報告している ${ }^{18)}$

今日, 唾液腺分泌機構には， $\beta$-フドレナリン受容体を 介する反応，および， $\alpha$ アアドレナリン， ムスカリン受容 体を介する反応が知られている ${ }^{19)}$ ，イソプロテレノール などの $\beta$ アアドレナリン作働性刺激薬は, 膜のアデニルシ クラーゼを活性化し, 細胞内 cyclic AMP が上昇して, cyclic AMP は protein kinase を活性化し, 開口分泌 の機序によりアミラーゼなどの蛋白またはムュ蛋白の分 泌を促進する。このように, カテュールアミンの $\beta$-効果 により, 唓夜腺細胞增殖促進, 唾液分泌促進, 線維芽細 胞抑制などの一見異なる作用が若起されるわけであり，

これら $\beta$-作用の関連性については, 今後解明されるべき 課題となっている.

また，イソプロテレノール投与により細胞性シートが 良好に維持される効果については, 腺上皮細胞に対する 直接作用，および，線維芽細胞抑制による二次的効果， の 2 通りの可能性が考えられる. しかし, イソプロテレ ノールによる $\beta$-効果は，上述したごとくさまざまの作用 を及ほすす可能性があるわけであり，唾液腺の上皮様細 胞, 線維芽細胞様細胞の両者に作用した結果, 細胞性シ 一トが長期間良好に維持される, と考えるのが妥当であ ろら.

\section{結論}

ヒト唾液腺初代培着細胞（組織片培養）を用いて，そ の增殖性に及ぼすイソプロテレノールの効果を検討し た. イソプロテレノールは, 最終濃度 $10^{-4}, 10^{-5}, 10^{-6}$, $10^{-7} \mathrm{~g} / \mathrm{ml}$ となるように培地中に添加した。

イソプロテレノール非添加の場合，形成された細胞性 シートは, $4 \sim 6$ 週後頃より変性し, 多くの場合, 線維 芽細胞様細胞が優性となった。これに対して, $10^{-5} \mathrm{~g} / \mathrm{m} l$ のイソプロテレノール添加群では，上皮性細胞が充実性 に増殖し，凹凸や細胞消失の少ない細胞性シートが形成 され，かつ，その状態が長期間維持されることが明らか になった。一方, 線維芽細胞様細胞の增殖に対しては, 著明な抑制効果が認められた。イソプロテレノールのこ れらの作用は， $\beta$-効果による細胞内 cyclic AMP 澧度 上昇に関連したものと考えられた。

本研究の要旨の一部は, 第 4 回ヒト細胞研究会 (炤和 61年 8 月, 東京), 扣よび第 31 回日本口腔外科学会総会 （昭和 61 年 10 月，久留米）に招いて発表した。

本研究費の一部は, 昭和59年度文部省科学研究费補助 金（奖励研究 A No. 59771528）によっている.

\section{引用 文 献}

1) Brown-Grant, K.: Enlargement of salivary gland in mice treated with isopropylnoradrenaline. Nature 191: 1076-1078 1961.

2) Selye, H., Veilleux, R., et al.: Excessive stimulation of salivary gland growth by isoproterenol. Science 133: 44-45 1961.

3) Kreider, J.W.: Stimulation of DNA synthesis of rat salivary gland cells in monolayer cultures by isoproterenol. Cancer Res. 30: 980-983 1970.

4）本間燕晴：ラット耳下腺ならびに䫑下腺勫胞の 初代培着に対するIsoproterenol の作用につい て. 㳡学 65: 524-538 1977.

5) Lamey, P-J., Ferguson, M.M., et al.: The growth and ductal epithelial cell response of mouse submandibular salivary glands to selected neurotransmitters in vitro. Arch Oral Biol 27: 747-751 1982.

6）武市宣雄：X線照射によるラット唾液腺腫瘍の 誘発 その 2 . 長期実験における唾液腺腫湯の 発生. 広大医誌 23: 391-411 1975.

7) Shklar, G. and Cataldo, E.: Effects of a chemical carinogen on the submaxillary gland of albino rats treated with isoproterenol. Cancer Res 26: 1319-1323 1966.

8) Borsanyi, S. J.: Chronic asymptomatic enlargement of the parotid glands. Ann Otol 71: 857-867 1962.

9）井上秀夫, 小西洋太郎, 他 : 培養ラット耳下腺 のホルモン応答性に関する研究。曾基礎誌 24 : 370-378 1982.

10）竹村晴夫, 大鹿英世： $\alpha$-および $\beta$-アドレナリン 作働薬に対するラット耳下腺分離細胞の反応性 について。杉幌医誌 51：429-437 1982.

11）山本笅, 石田 甫: カテュールフミンと唾液 腺細胞增殖。萄基礎誌 18：379-395 1976.

12）日本組緎培䬸学会編：細胞成長因子第 1 版。 朝食盽店, 東京, 130-134頁, 1984.

13）山田雅保, 沖垣 達: 上皮細胞の增殖と成長因 子生体の科学 331: 381-388, 1982.

14）宮田和幸：ヒト血液腺由来細胞の培条条件扣上 び增殖動態に関する研究. 和歌山医学 $36: 255-$ 2681985.

15) Mangos, J.A., McSherry, N.R., et al.: Dispersed rat parotid acinar cells. I. Morphological and functional characterization. Am J Physiol 229: 553-559 1975.

16) Inoue, K., Horiuchi, R., et al.: Effect of thyrotropin on cell orientation and follicle reconstruction in rotated suspension culture of hog thyroid cells. Endocrinology 107: 1162-1168 1980.

17) Mauchamp, J., Margotat, A., et al.: Polarity of threedimensional structures derived from isolated hog thyroid cells in primary culture. Cell Tiss Res 204: 417-430 1979. 
18) Oliver, C.: Isolation and maintenance of differentiated exocrine gland acinar cells in vitro. In Vitro 16: 297-305 1980.
19）岩月矩之, 西山明德：外分泌腺房細胞の電気生 理一ラット・マゥスの膵臓, 唾夜腺, 涙腺を中 心として一 生体の科学 31: 410-421 1980. 